\title{
ОРГАНИЗАЦИЯ ПСИХОЛОГИЧЕСКОГО СОПРОВОЖДЕНИЯ РАЗВИТИЯ ПРОФЕССИОНАЛЬНОГО САМОСОЗНАНИЯ СТУДЕНТОВ
}

\author{
Е. Е. Иванова \\ Московский гуманитарный университет
}

\begin{abstract}
Аннотация: В статье рассматриваются особенности психолого-педагогического сопровождения развития профессионального самосознания студентов вуза. Анализируются психолого-педагогических условия, влияющие на эффективность развития профессионального самосознания студентов на разных этапах обучения.
\end{abstract}

Ключевые слова: профессиональное самосознание; психолого-педагогическое сопровождение; профессиональное самосознание; студенты

\section{ORGANIZATION OF PSYCHOLOGICAL SUPPORT FOR THE DEVELOPMENT OF STUDENTS' PROFESSIONAL SELF-} \section{AWARENESS}

\section{E. E. Ivanova \\ Moscow University for the Humanities}

\begin{abstract}
The article considers features of psychological support for the development of university students' professional self-awareness. It analyses psychological and pedagogical conditions affecting the effectiveness of the development of students' professional self-awareness at different stages of training.
\end{abstract}

Keywords: professional self-awareness; psychological and pedagogical support; students

Современные кризисные реалии определяют особенности рынка рабочей силы, характеризующиеся условиями негарантированной занятости. Гарантий никаких нет, что выпускник высшего учебного заведения сразу найдет себе работу по специальности и будет иметь рабочее место на протяжении всей трудовой жизни. В этих условиях особое значение приобретают проблемы развития профессионального самосознания на самых ранних сроках обучения, позволяющие самостоятельно разрабатывать траекторию трудового пути. В общеметодологическом плане изучения проблем профессионального самосознания представляют интерес работы исследователей: Л. М. Митиной (Митина, 2010), Ю. А. Сторожевой (Сторожева, 2013), С. А. Печерской (Печерская, 2010).

Основные цели образовательного процесса в вузе не должны сводиться только к формированию определенного объема знаний, умений и навыков, как основы компетенций. Вузам важно уделять внимание сопровождению и поддержке представлений студента о целостном образе 
себя как профессионала, заложить основы профессионального мировоззрения, профессионального кредо, сформировать понимание и принятие будущим специалистом в той или иной области норм, правил, моделей своей профессии как эталонов для осознания и оценки своих качеств.

Сопровождение развития профессионального самосознания ориентируется на актуализацию частной инициативы студента, на полную реализацию индивидуальных возможностей, на поддержку и поощрение творческих способностей, на создание условий для свободного выбора жизненного и профессионального пути через реализацию своих планов. Обусловлено это тем, что главным в работе профессионала является он сам, его личность, умение реализовать свои профессиональные и жизненные намерения.

Несмотря на происходящие в образовании «преобразования, призванные обеспечить переход от системы массового ... к индивидуализированному образованию» (Постановление Правительства РФ ..., Электр. ресурс), одним из недостатков высшей школы в подготовке профессионала является ориентация большого количества преподавателей на решение образовательной задачи, связанной с формированием у студентов только прочных научно-предметных знаний. Конечно, знаниевая парадигма является составляющей профессиональной подготовки, но, в современных условиях, она не обеспечивает сформированного умения самостоятельно проявлять себя в избранной профессиональной деятельности (Ильинский, Гуревич, 2006; Батколина, 2012) .

Актуализация данных процессов возможна через осмысление и перестройку профессионально-личностного опыта на основе рефлексивнотворческой деятельности.

Этому может способствовать внедрение в образовательную практику вуза психологического сопровождения, формирующего и развивающего профессиональные намерения и поддерживающего профессиональное самосознание, позволяющее наиболее гибко осуществлять профессиональную деятельность в социальных условиях негарантированной занятости.

Психологическое сопровождение развития профессионального самосознания в процессе обучения в вузе предусматривает не только установление связей между содержанием формируемых компетенций, но и является условием совместного с обучаемым определением его интересов, ценностей, возможностей и путей преодоления препятствий в будущей профессиональной деятельности, формирования качеств личности важных для будущей профессии.

Эффективностьразвитияпрофессиональногосамосознаниястудентов на разных ступенях обучения зависит от ряда психолого-педагогических условий, о которых мы писали ранее с соавтором Т. В. Тараскиной: 
- условий методологического характера, которые заключаются в воспитании системы взглядов и убеждений как основы формирования научного мировоззрения и профессионального мышления, позволяющего снизить воздействие социального противоречия, обусловленного современным разделением труда, стремлением достичь определенных результатов в профессиональной деятельности, обозначить свое место в референтной профессиональной группе и личностным продвижениям студента;

- условий конструктивного (регулятивного) характера, связанного с созданием индивидуализированной, профессионально ориентированной системы обучения, использующей инновационные технологии, с целью формирования профессиональной направленности личности;

- условий интеграционного характера, состоящих в дополнении общеобщепрофессиональных компетенций профессиональными компетенциями, согласованными с профессиональными стандартами, для конструирования будущей профессиональной деятельности;

- условий мотивационно-потребностного характера, которые способствуют стремлению достичь определенных результатов в профессиональной деятельности и являются стимулом для дальнейшего статусного продвижения в конкретной профессиональной ситуации;

- условий гуманистического характера, предполагающих организацию развития профессионального самосознания с учетом личностного начала. Это выражается в анализе кризисных профессиональных ситуаций, рисков и отрицательных последствий профессиональной деятельности;

- условий социального характера, при которых развитие профессионального самосознания укрепляет понимание человека, как части природы и самоценности его личности, и позволяет создавать условия для удовлетворения потребностей по активизации присущих индивиду способностей и возможностей;

- условий экономического характера, отвечающих за целенаправленную подготовку молодого поколения к условиям негарантированной занятости, к необходимости поиска и получения студентом информации, позволяющей реализовать запасные профессиональные стратегии (Тараскина, Иванова, 2008а).

Учет выше обозначенных условий при организации психологического сопровождения развития профессионального самосознания позволит укрепить положительное отношение к будущей профессии, интерес, склонности, способности к ней, стремление повышать свою квалификацию после окончания вуза.

Важнейшими условиями, обеспечивающими эффективность сопровождения являются, по нашему мнению: обеспечение создания об- 
разовательной среды, предусматривающей предоставление обучающимся широкого спектра профилей обучения, ориентированного на развитие личностных качеств; осуществление комплексной деятельности профессорско-преподавательского состава, направленной на оказание поддержки студентам на всех этапах развития и реализации их профессионального самосознания; использование личностно и практикоориентированных технологий, формирующих, развивающих и поддерживающих профессиональное самосознание.

Психологическое сопровождение, как мы писали, решает следующие задачи:

- определение личностного потенциала, актуализация его в процессе развития профессионального самосознания;

- осуществление поддержки формирования профессионального самосознания студента в образовательной практике вуза;

- актуализация в сознании студентов стремления к самореализации «через увлеченность значимой работой» (Тараскина, Иванова, 2008b).

Для успешной реализации данных задач необходим учет ряда составляющих (Лидак, Иванова, 2008).

Дидактическая составляющая, включающая в себя создание образовательной базы для проведения занятий и организации самостоятельной работы студентов, разработку программ рабочих дисциплин или факультативов, являющихся профессионально определяющими: «Введение в профессию» или «Введение в педагогическую науку». При формировании общепрофессиональных компетенций, важно учитывать не только знания, умения, навыки по разделам дисциплины, но и информацию о возможностях развития личностного и профессионального самосознания в рамках данного направления подготовки. Особое внимание важно уделить организации практик (учебной и производственной) их непрерывности и разноплановости, позволяющих наиболее адекватно представлять всю специфику разных направлений своей будущей профессиональной деятельности.

Организационная составляющая основным предназначением которой является формирование и развитие профессионального самосознания на принципах индивидуально-личностного и деятельностного подходов.

Практическая составляющая не затрагивает учебный процесс, а направлена на необходимость организации работы психологической службы факультета или вуза. Работа психологический службы, в первую очередь должна быть направлена на помощь студентам в решении актуальных для них проблем личностного и учебно-профессионального развития в период обучения. Психологическое консультирование по проблемам профессионального самосознания может быть представлено в двух ипоста- 
сях: индивидуальное, направленное на решение личностных проблем, тормозящих развитие самосознание в профессии, а также тренинговые занятия, позволяющие реализовать себя через занятия в группе. С этой целью могут быть использованы комплекты профессиограмм профессий, презентации о профессиях.

Необходимо также осуществлять повышение квалификации профессорско-преподавательского состава с целью переориентации его с учебно-дисциплинарной на личностную модель взаимодействия со студентами.

$\mathrm{K}$ практической составляющей психологического сопровождения можно отнести внеаудиторную работу, включающую организацию и проведение конкурсов исследовательских работ (в Московском гуманитарном университете - конкурс студенческих работ СНВ), дней профессий.

На основании вышеизложенного, учитывая выявленные в результате эмпирического исследования особенности развития профессионального самосознания студентов на различных этапах обучения, наиболее эффективными направлениями психологического сопровождения являются следующие.

На первом этапе (1,2 курс) - развитие положительного отношения к выбранной профессии, к образу и стилю деятельности ее представителей; актуализация имеющихся и формирование новых базовых профессионально важных качеств и компетенций; коррекция понимания роли избранной профессии в жизни человека и общества. Это может быть реализовано при организации учебной практики и внеаудиторных занятий, на которых студенты смогут первично соотнести собственные способности с требованиями выбранной ими профессии, получить информацию о технологиях, условиях труда и профессиональных обязанностях работников.

На втором этапе (3 курс) - формирование профессионального самосознания внутри конкретной профессиональной области; совершенствование базовых профессионально значимых качеств и знаний в рамках производственной практики.

На третьем этапе (4 курс) - расширение личной базы профессиональных умений студентов, формирование умений адекватно оценивать, корректировать и совершенствовать свои возможности в профессии, включая поиск рабочего места, навыки самопредъявления.

В качестве конкретных форм реализации данных направлений, осуществляемых в Московском гуманитарном университете, можно выделить следующие:

- деятельность студенческого информационного центра, целью которого является расширения комплекса информационных услуг, создание условий для самостоятельного получения информации и работы с ней, 
использование информационных технологий, сети Интернет;

- ведение специализированных курсов по сопровождению карьеры: изучение себя, своих личностных и психологических качеств, особенностей профессиональной деятельности, требований современного рынка труда. В университете ведется профориентационная работа, включающая компьютерную диагностику, тестирование, проведение тренингов с целью выявления личностных и профессиональных качеств выпускников;

- внедрение программ обучения навыкам поиска работы (в университете на мастер-классах студенты учатся составлять резюме, осваивают методы самопрезентации и техники проведения собеседования с работодателем, знакомятся с технологиями поиска работы.);

- обеспечение последовательности и преемственности в оказании услуг по сопровождению карьеры человека (в Московском гуманитарном университет совместно с Центром содействия трудоустройству осуществляется взаимодействие со специалистами в области карьеры и работодателями).

Таким образом, психолого-педагогическими условиями сопровождения, позволяющими развивать профессиональное самосознание студентов являются: осознание первоначальной цели получения высшего образования, позволяющее влиять на ценностно-смысловые отношения, определяющие профессионально-личностную позицию; психологопедагогическое сопровождение процесса становления будущего «профессионала»; практико-ориентированный характер обучения, организация которого позволяет создать среду, отражающую предметное и социальное содержание будущего профессионального труда и системы профессиональных отношений; поддержание профессиональных намерений и интереса, побуждающих к саморазвитию и самореализации личности в конкретной профессиональной деятельности.

\section{СПИСОК ЛИТЕРАТУРЫ}

Постановление Правительства РФ от 23 мая 2015 г. N 497 «О Федеральной целевой программе развития образования на 2016-2020 годы» (с изменениями и дополнениями) [Электронный ресурс] // Гарант. Информационно-правовое обеспечение. http://base.garant. $\mathrm{ru} / 71044750 / \# i x z z 4 o Z s D J 8 X b / /$ (дата обращения: 25.07.2017).

Батколина, В.В.(2012) Инновационные подходы в образовании взрослых. М. : Из-во «Российский новый университет». 200 с.

Ильинский, И. М., Гуревич, П. С. (2006) Понимание как цель образования // Знание. Понимание. Умение. № 1. С. 5-15.

Лидак, Л. В., Иванова, Е. Е. (2008) Психологическое сопровождение развития профессиональных намерений студентов вузов в условиях не- 
гарантированной занятости. Пятигорск ; Минеральные Воды: Пятигорский государственный лингвистический университет. 139 с.

Митина, Л. М. (2010) Психология профессионального развития личности: теоретико-методологические проблемы // Российский научный журнал. № 14 . С. 57-63.

Печерская, С. А., Романова, Д. Е. (2010) Теория и практика формирования профессионального самосознания студентов-психологов в условиях современного вуза. М. : Спутник+. 165 с.

Сторожева, Ю. А. (2013) Социально-психологические особенности профессионального самоопределения студенческой молодежи : автореф. дисс. ... канд. псих. н. М. 25 с.

Тараскина, Т. В., Иванова, Е. Е. (2008а) Профессиональное самосознание как психологическое условие профессионального и личностного развития студентов технического вуза. Астрахань: ИП Сорокин Роман Васильевич. 124 с.

Тараскина, Т. В., Иванова, Е. Е. (2008b) Психологическое сопровождение развития профессионального самосознания студентов технического вуза. Методическое пособие. Астрахань: ИП Сорокин Роман Васильевич. $114 \mathrm{c}$.

Дата поступления: 14.07.2017 г.

Иванова Екатерина Евгеньевна - кандидат психологических наук, доцент, доцент кафедры педагогики и психологии высшей школы Московского гуманитарного университета. Адрес: 111395,Россия, г. Москва, ул. Юности, д. 5. Тел.: +7 (499) 374-74-59. Эл. адрес: katriniva@mail.ru

Ivanova Ekaterina Evgenievna, Candidate of Psychology, Associate Professor, Department of Pedagogy and Psychology of Higher School, Moscow University for the Humanities. Postal address: 5, Yunosti St., Moscow, Russian Federation 111395. Tel.:+7 (499) 374-74-59.E-mail: katriniva@mail.ru

\section{Для циитирования:}

Иванова Е. Е. Организация психологического сопровождения развития профессионального самосознания студентов [Электронный ресурс] // Научные труды Московского гуманитарного университета. 2017, № 4. URL: http://journals.mosgu.ru/trudy/ article/view/528 (дата обращения: дд.мм.гг.). DOI: 10.17805/trudy.2017.4.6 